\title{
Asian-European doctoral curriculums comparative research: A design perspective in comprehensive universities
}

\author{
Fan Chen ${ }^{*}$ \\ a College of Design and Innovation, Tongji University \\ *Corresponding author e-mail: chenfantj@foxmail.com
}

\begin{abstract}
:
Both Asia and Europe had established doctoral programs in design since the 1990s, immediately they began to collaborate and send exchange students to each other in order to maintain a partnership. However, academic cooperation had not deepened with the increasing scale of exchange students between the two regions, from which one of the results was some Asian doctoral programs iterate slowly. For instance, Chinese doctoral education in design (DED) had just started to explore an appropriate pedagogy in the last few years, and the homogeneous phenomenon was emerging. Based on the issues mentioned above, the researcher aimed to investigate the divergence of doctoral programs in design under a selected six-curriculum perspective by comparative study. Then recommendations toward curriculum and interregional coordination were proposed to improve the isolated education condition of some doctoral programs.
\end{abstract}

Keywords: design education; doctoral education in design; curriculum; interregional coordination

\section{Introduction}

As the highest level of the three-level higher education degree, the doctorate undertakes the functions of creating knowledge, cultivating people, and consolidating the foundation of disciplines. The development of design doctorate in Mainland China began in the 1980s (Zhang, 2015). In 1990, China trained the first doctor of industrial design, Lu Yong-Yi, whose research direction was the history of industrial design ("The first," 1991). With the development of design theory research, Chinese DED programs began to be established at the end of the 20th century, and showed an accelerated growth after 2011. Design education in China places great emphasis on art and technology, which makes students invest a lot of time in cultivating skills. This leads to unified teaching materials, unified outlines, and unified curriculums (Li, 2012). In order to improve this situation, the proportion of general-purpose courses has been increased in the teaching of doctors of 
design, focusing on professional ethics, collaboration skills, critical thinking, social responsibility training, and cultivating transferability (Wang \& Zhao, 2017). This emerging trend is still in its infancy among the 19 DED programs in mainland China, and a mature education model has not been formed. This status quo also exists in other Asian countries. Based on this, the study attempts to explore the DED teaching and courses from the perspective of curriculum settings, and to provide reference for researchers in the field.

\section{Literature review}

The doctorates first appeared, followed by the master and the bachelor degrees, reflecting the trend of education from the elite to the masses: In the 1950s, design education entered comprehensive universities (Friedman, 2002); In 1991, the first Doctor of Philosophy in Design in the United States was established in the School of Design at the Illinois Institute of Technology (Whitney, 2020); In 1992, the British polytechnic universities were transformed into comprehensive universities, and the doctor of design was established (Durling, 2013).

Although the characteristics of DED programs differ, the challenges they face are universal, mainly involving four aspects: creating new knowledge, preserving existing knowledge, training professionals, and cultivating citizens (Friedman, 2002). In the development of doctoral education for more than two hundred years, the training of research doctors has formed two models, one is the 'European model' (also known as the 'German model') and the other is the 'North American model'. In the European model (including Australia), doctoral students are regarded as independent researchers, they communicate with their supervisors and complete a dissertation with no formal courses. On the other hand, the structural research training through compulsory and elective courses is the North American doctoral model. Doctoral students need to take a large number of courses before presenting research questions (Shen \& Wang, 2010). It includes research skills courses, method training, subject frontier courses, language training, and other training, this requires several years to do coursework. However, the North American model has recently become part of the European and Australian doctoral programs since the 1980s. Under the influence of the North American model, countries such as Germany, France, the United Kingdom, Denmark, and the Netherlands have established graduate schools to provide a structured institutional environment for doctoral education. The trend from the European model to North American resulted from a largescale expansion of enrollment, which can be attributed to the promotion of the knowledge economy, increasing demand for doctors, and diversifying labour markets. The development of DED has spawned discussions on the characteristics of appropriate doctoral programs (Melles, 2009). The development of Asian DED programs was late to Europe and North America. After learning from Europe and North America, they have also formed their characteristics. For example, Japan has introduced the graduate school system and the German lecture system (Li, 2015).

Nevertheless, the global dissemination of the structured curriculum of the doctor of design has not yet been verified (Melles, 2009). It can be seen that different curriculum settings cause communication barriers, and a unified core course group can be established to build a platform for the exchange of design doctors (Margolin, 2010). Friedman (2015) responded to the above status quo. He advocated that the doctoral education system should include these contents: expertise, research methods, research skills, teaching methods of training graduate students. And Victor Margolin (1999) believed that history, theory, and criticism should play a central role in different fields of design research and should be part of the curriculum of the design doctoral education program. 
DED programs are responding to Friedman and Margolin's initiatives. The Delft University of Technology established the IDE project in 1969 and set five curriculum goals (Voûte et al., 2020). The first Turkish design doctorate was established in 1982. All academic fields were forced to establish a standard academic framework (Alpay Er, 1999). Carnegie Mellon University established the Transition Design PhD program in 2014, which involves system-level transformation to support design (School of Design, Carnegie Mellon University, n.d.). The doctoral program of design at Soochow University requires special discussions on cutting-edge topics in design and art theories (Li, 2011). In the China Academy of Art, the doctoral supervisors ask students to choose a subject and analyze the structure (Yin, 2014).

To achieve the above situations, diversified resources for doctoral students should be supported, such as well-educated researchers, a department that provides curriculum development, coordination with other departments projects, and good academic administration (Friedman, 2015). At the same time, comprehensive research culture is conducive, including reader reports on drafts of thesis, proposal for doctoral course report, doctoral annual report, cross-regional and cross-themed doctoral design project (Morrison et al., 2015). On the other hand, doctoral education should consider the possibility of distance learning.

The researcher found that the existing research cases are mainly from English-speaking countries, and there are little researches on the DED programs in Asia. Therefore, the research question is raised: Under the background that European and American systems dominate the mainstream, what kind of Asian design doctoral education and curriculum structure can cultivate future-oriented design researchers? In response to this question, the researcher tried to explore the structure of the doctoral course of design and put forward corresponding suggestions.

\section{Methodology}

Teaching structure refers to teaching objectives, teaching content, teaching organization forms, etc. This is one of the most important sessions in doctoral training. The curriculum belongs to the teaching content indicating the combination of different types of courses (Jiang, 1998). After a literature study, six DED programs have been selected between Asia and Europe according to the principle of purposeful sampling, which is to extract the research objects that can provide the greatest amount of information for the research problem (Patton, 1990). Then researcher compared their curriculums based on the official instructions (Aalto University. n.d.; Politecnico di Milano, n.d.; Delft University of Technology, n.d.; Tongji University, 2020; School of Design, Kyushu University, n.d.; Department of Industrial Design, Korea Advanced Institute of Science and Technology, n.d.). These programs are affiliated with Aalto University, Politecnico di Milano (Polimi), Delft University of Technology (TUDelft), Tongji University, Kyushu University, and Korea Advanced Institute of Science and Technology (KAIST) respectively. They were selected because all of them can be regarded as comprehensive universities and owned a highly educational reputation, which makes it valuable to explore their educational strategy based on this common quality. Furthermore, this study also intended to explore the future development in view of their long-term coordination.

Given the findings of literature review, the researcher proposed a conceptual model to inquire about these curriculums, which consists of four sections: Knowledge, Approach, Skill, and Pedagogy. Therefore, the model is called SPAK according to the four initials (Figure 1). As we all knew, the curriculums used to be categorized into compulsory courses, elective courses, practical sections, and administrative requirements. However, the SPAK provides another taxonomy in this study, which is 
used to explore the educational tendency of each program. Additionally, the classification of each course is based on the content given by their official instruction.

It should be noted that courses related to building environments and arts, such as architecture, painting, sculpture, and film, were off the table. In addition, the courses suit for both master and doctoral students had been rejected, which was to ensure this study focus on the doctoral curriculum.

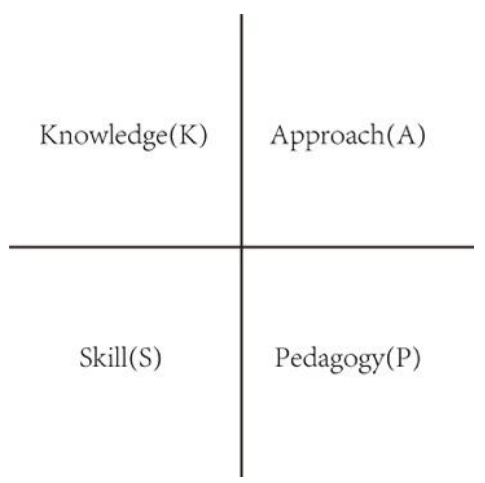

Figure 1. SPAK course model, made by the researcher.

\section{Analysis}

The researcher integrated the courses into the SPAK model by qualitatively analyzing their training goals. Figure 2 and 3 reflect the classification of the six curriculums, in which knowledge-related courses are engaged in the red area, approach in yellow, skill in green, and pedagogy in blue. In this study, 167 courses have been investigated, respectively Aalto contributed 26 courses, Polimi 29, TUDelft 56, Tongji 18, Kyushu 29, and KAIST 9. It can be seen from the two figures, the three European doctoral programs tend to provide more courses than the Asian's, they are 111 and 56 correspondingly. Additionally, the knowledge area has 44 courses totally, the approach has 35 , the skill has 82 , and the pedagogy has 6 .

\subsection{Knowledge}

The six programs tend to provide horizontal and vertical knowledge to doctoral candidates, horizontal is used to open their eyes, then vertical is to strengthen the professional and academic foundation. They involve the fundamental condition of the program, cultural literacy, and ethics.

It is interesting to find that Aalto, Polimi, and TUDelft regard the introduction of doctoral program as an individual course toward students, throughout which the study journey will be informed. While the Asian programs prefer to engage this part into a lecture during the welcome week, such as Tongji.

Design and liberal arts knowledge constitute cultural literacy. Students are expected to master interdisciplinary knowledge by reading literature and flipped discussion. They refer to design-related policy, governance, management, industry, business, philosophy, epistemology, and cognition. On the other hand, liberal arts knowledge in this study indicates cultural common sense within other disciplines, like the classics appreciation, European culture, and architecture criticism, which are planned in the first year of doctoral study. However, liberal arts occupy a little scale in the 167 courses, then TUDelft, Kyushu, and KAIST have not provided these pieces of knowledge yet. 
Academic ethics help to establish a responsible mindset for doctoral students and academia. Except for Kyushu and KAIST, the rest four DED programs have provided ethical courses under different perspectives. For instance, besides research ethics, Polimi and TUDelft also offer technology and engineering ethics to students.

\subsection{Approach}

According to the statistics, the approach area is composed of qualitative research methods, quantitative research methods, and academic writing guidance. They are usually taught with software tools, such as SPSS (Statistical Product and Service Solutions). Apart from academic methods, some programs provide study tips to improve learning efficiency: Polimi enables students to write both papers and articles, the latter aims to disseminate knowledge effectively; TUDelft instructs to make posters with Adobe Indesign. Kyushu and KAIST do not offer individual approach courses temporarily.

\subsection{Skill}

The proportion of skill-related courses tops the whole curriculum. After classifying the qualities, 82 skill courses cover 11 fields of competencies, which involves foreign language writing, presentation, interview, communication, negotiation, organization, management, leadership, decision-making, commercial operation, and personal branding. These skills can be regarded to prepare for either academic or practical working opportunities, and they have been especially emphasized by Polimi and TUDelft. Moreover, Aalto, Tongji, Kyushu, and KAIST seldom treat skill courses as an independent section, but integrate them into projects, like doctoral summer school, internship, seminar, and design studio. According to the course information, some programs tend to combine approach and skill courses into one, such as Kyushu and KAIST.

\subsection{Pedagogy}

Teaching ability had been seen as essential competence when doctors graduated in the last few decades. However, diversified choices of vocation gradually guide them to other fields, this also reflects the changing societal needs. Currently, only Polimi, TUDelft, and Tongji have provided this training, and Tongji puts it into a teaching practice project and considers doctoral candidates as teaching assistants to help with administrative work.

\section{Discussion}

\subsection{The quantity of curriculums}

The three European curriculums had been iterating ever since the U.S. formulated its doctoral pedagogy and gained wider acceptance. This also progressed the original aims of the Bologna Process: rationalize education, increase mobility, expand resources, shorten completion cycles, and reduce costs (Friedman, 2015). Among them, the period of learning cycles and the costs may increase: the enlarging curriculums need more time and capital costs to finish. On the other hand, although Asian doctoral education in design started not later than European -Tongji in 1991 ("The first", 1991), Kyushu in 1993 (School of Design, Kyushu University, n.d.), and KAIST in 2002 (Department of Industrial Design, Korea Advanced Institute of Science and Technology, n.d.) - they tend to absorb western didactics and maintain the domestic educational traditions as well. This can be reflected in the balance between knowledge and approach courses: Tongji, Kyushu, and KAIST add 
social science into the curriculum, but there is no research method except Tongji, most of which have been integrated into the skill courses taught within projects.

\begin{tabular}{|c|c|c|c|c|}
\hline & Knowledge & Approach & Skill & Pedagogy \\
\hline Aalto & $\begin{array}{l}\text { Department of Design Winter } \\
\text { School } \\
\text { Design in Policy and Governance } \\
\text { Introduction to Doctoral Studies } \\
\text { Living Classics } \\
\text { Managing Design: Reading } \\
\text { Seminar } \\
\text { Philosophy of Science } \\
\text { Research Ethics } \\
\text { Strategic Co-Design Reading } \\
\text { Sustainability Politics } \\
\text { The Philosophy of Knowledge and } \\
\text { Skills } \\
\text { Values in Design Futures }\end{array}$ & $\begin{array}{l}\text { Creative Writing and Other } \\
\text { Discourses } \\
\text { Department of Design Thematic } \\
\text { Research Seminar } \\
\text { Experience Research Methods } \\
\text { Intersections Between Sustainabili- } \\
\text { ty and Design } \\
\text { Introduction to Design Research } \\
\text { Methods of Analysing Qualitative } \\
\text { Data } \\
\text { Methods of Gathering Qualitative } \\
\text { Data } \\
\text { Preparing for the Doctoral } \\
\text { Defence } \\
\text { Presenting Doctoral Research } \\
\text { Techniques for Analyzing Digital } \\
\text { Data } \\
\text { Writing Doctoral Research }\end{array}$ & $\begin{array}{l}\text { Argumentation Skills } \\
\text { Doctoral Seminar } \\
\text { Nida Doctoral Summer School } \\
\text { Practices of Presenting Research }\end{array}$ & \\
\hline Polimi & $\begin{array}{l}\text { Design Research Critique } \\
\text { Design Research Prototyping } \\
\text { Epistemology of Scientific and } \\
\text { Technological Research } \\
\text { Ethics and Technology } \\
\text { Ethics in Research } \\
\text { European Culture } \\
\text { New Demographics. Science, } \\
\text { Technology and Design Facing } \\
\text { The "Grand Challenge" of Ageing } \\
\text { Scientific Reasoning: Philosophy, } \\
\text { Logic and Applications } \\
\text { The Process of Research }\end{array}$ & $\begin{array}{l}\text { Design Research Methodologies } \\
\text { Exploring Public Debates } \\
\text { Surrounding Academic Topics } \\
\text { through Data Driven Approaches } \\
\text { Research Skills } \\
\text { Science, Technology, Society and } \\
\text { Wikipedia }\end{array}$ & $\begin{array}{l}\text { Advanced Interaction Skills for } \\
\text { Academic Professionals } \\
\text { Communication Strategies that } \\
\text { Score in Worldwide Academia } \\
\text { Design Research Contexts and } \\
\text { Resources } \\
\text { English for Academic } \\
\text { Communication } \\
\text { Industrial Skills } \\
\text { Professional Communication } \\
\text { Project Management (in Action) } \\
\text { Project Management Basics } \\
\text { Resource Planning and } \\
\text { Management within Sustainable } \\
\text { Development } \\
\text { Risk, Resilience, and } \\
\text { Sustainability in Science and } \\
\text { Engineering } \\
\text { Scientific Communication in } \\
\text { English } \\
\text { Strategic Decision Making } \\
\text { Sustainability Metrics, Life Cycle } \\
\text { Assessment and Environmental } \\
\text { Footprint } \\
\text { Technology \& Society } \\
\text { User Centred Innovation }\end{array}$ & Innovative Teaching Skills \\
\hline TUDelft & $\begin{array}{l}\text { Engineering Ethics } \\
\text { IDE Research Course } \\
\text { PhD Start-up } \\
\text { Research Design }\end{array}$ & $\begin{array}{l}\text { Creative Tools for Scientifc } \\
\text { Writing } \\
\text { Data Visualisation as A Tool for } \\
\text { Scientific Research } \\
\text { Data Visualisations - A Practical } \\
\text { Approach } \\
\text { Designing Scientific Posters and } \\
\text { Lay-out for Theses with Adobe } \\
\text { InDesign } \\
\text { Discovering Statistics Using SPSS } \\
\text { Effective Management of your } \\
\text { PhD Research } \\
\text { How to Make A Questionnaire } \\
\text { and Conduct An Interview } \\
\text { Making an Impact with Open } \\
\text { Science } \\
\text { Managing the Academic } \\
\text { Publication Review Process } \\
\text { Speedreading and Mindmapping } \\
\text { The Informed Researcher: } \\
\text { Information and Data Skills } \\
\text { Writing a Dissertation }\end{array}$ & $\begin{array}{l}\text { Achieving Your Goals and } \\
\text { Performing More Successfully in } \\
\text { Your PhD } \\
\text { Advanced Problem Solving and } \\
\text { Decision-Making: Thinking an } \\
\text { Outsidel/Inside/Getting-rid of the } \\
\text { [Research] Box } \\
\text { Advanced Self-presentation: } \\
\text { Persuasian, Structure and } \\
\text { Visualisation } \\
\text { Analytic Storytelling } \\
\text { Brain Management } \\
\text { Career Development - Design } \\
\text { Your Next Career Move } \\
\text { Career Development - Exploring } \\
\text { a Research Career outside } \\
\text { Academia } \\
\text { Career Development - Looking } \\
\text { for Work in The Netherlands } \\
\text { Career Development - Marketing } \\
\text { Tools to Position Yourself in the } \\
\text { Job Market } \\
\text { Career Development - Personal } \\
\text { Branding, Presenting Yourself } \\
\text { Effectively } \\
\text { Career Development - } \\
\text { Personality Matters } \\
\text { Career Development - Preparing } \\
\text { for Your Next Career Step in } \\
\text { Academia } \\
\text { Career Strategies for Women in } \\
\text { Science } \\
\text { Conversation Skills } \\
\text { Cross Cultural Communication } \\
\text { Skills in Academia } \\
\text { Dutch for Foreigners } \\
\text { Effective Negotiation: Win-win } \\
\text { Communication } \\
\text { English for Academic Purposes } \\
\text { How to Formulate Successful } \\
\text { Propositions for Your PhD } \\
\text { Defense }\end{array}$ & $\begin{array}{l}\text { How to Keep Motivated after } \\
\text { Your GO? Regain Your Flow! } \\
\text { Interactive Online Self-presenta- } \\
\text { tion: Structure, Visualise, Focus } \\
\text { and Interact } \\
\text { Leadership, Teamwork and } \\
\text { Group Dynamics } \\
\text { Popular Scientific Writing } \\
\text { Preparing for an Assessment } \\
\text { Center } \\
\text { Presenting Scientific Research } \\
\text { Problem-solving and } \\
\text { Decision-making in Research } \\
\text { Self-awareness and Autonomy in } \\
\text { the Research Process } \\
\text { Self-management Strategies } \\
\text { Spoken English for Technologists } \\
\text { The Art of Presenting Science } \\
\text { Time Management } \\
\text { Turning Your Thesis into } \\
\text { Business } \\
\text { Using Creativity to Maximize } \\
\text { Productivity and Innovation in } \\
\text { Your PhD } \\
\text { Voice Training } \\
\text { Work Smarter, Stress Less } \\
\text { Writing a Scientific Article in } \\
\text { English }\end{array}$ \\
\hline
\end{tabular}


Figure 2. Classification of the six curriculums: Aalto, Polimi, and TUDelft, made by the researcher. Green and blue area shares the right row for type setting.

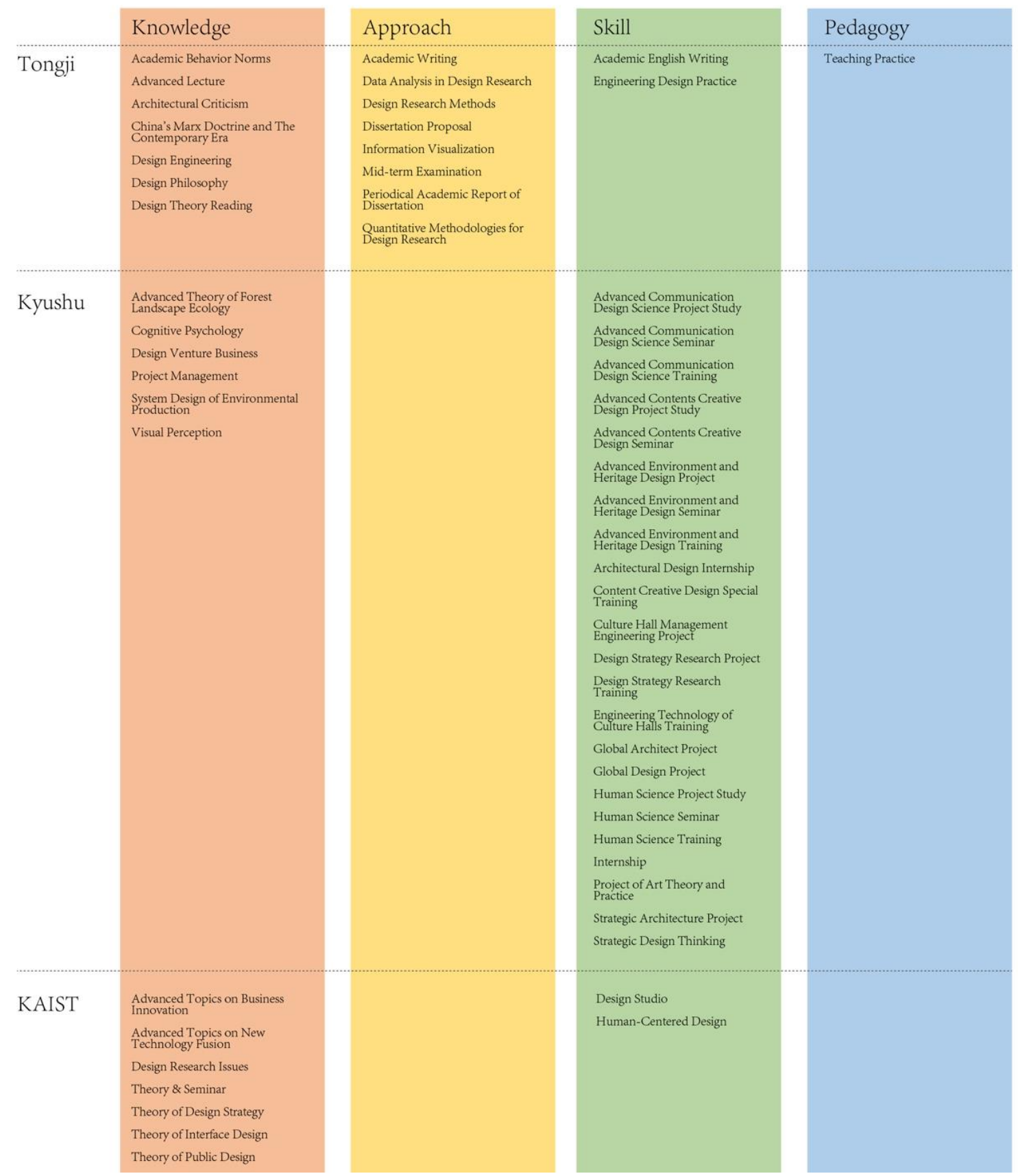

Figure 3. Classification of the six curriculums: Tongji, Kyushu, and KAIST, made by the researcher.

\subsection{The width and the depth of curriculums}

There is an indispensable phenomenon that existed among the six curriculums: Aalto, Polimi, and TUDelft tend to establish curriculums based on the future academic or professional requirements, and offer a large course pool for students to choose from; yet Tongji, Kyushu, and KAIST prefer to set five to six detailed research directions firstly, then establish curriculums based on these directions. In general, the difference between the two kinds of systems is whether there are knowledge course groups.

From the perspective of knowledge courses, the subject preference of each curriculum is clear (Table 1). Most curriculums import engineering knowledge, then arts and philosophy. This condition can 
result from two reasons: 1 . Though these universities are comprehensive, historically they have a strong quality of applied technology. 2. The urban and historic culture affect curriculums as well, for example, Milan has an overwhelming resource of arts and design, which inevitably influences its education. In addition, economics, law, management, and politics knowledge emerge in Aalto, Tongji, Kyushu, and KAIST, while Polimi and TUDelft have stronger engineering nature.

Table 1. Fields that knowledge courses refer to, made by the researcher.

\begin{tabular}{lcccccc}
\hline Name & Aalto & Polimi & TUDelft & Tongji & Kyushu & KAIST \\
\hline Arts & $\bullet$ & $\bullet$ & & & $\bullet$ & \\
\hline Economics & $\bullet$ & & & & $\bullet$ & $\bullet$ \\
\hline Engineering & $\bullet$ & & $\bullet$ & $\bullet$ & $\bullet$ & \\
\hline History & & $\bullet$ & & & & \\
\hline Law & $\bullet$ & & & & & $\bullet$ \\
\hline Literature & & $\bullet$ & & $\bullet$ & & \\
\hline Management & & $\bullet$ & $\bullet$ & & & \\
\hline Philosophy & $\bullet$ & & & $\bullet$ & $\bullet$ \\
\hline Politics & & & & & & \\
\hline Psychology & & & & & & \\
\hline Science & & & & & & \\
\hline
\end{tabular}

It is noted that TUDelft had just offered engineering knowledge, which responds to its mission: educating highly skilled doctors to make up for social needs with increasing complexity (Delft University of Technology, n.d.). As is stated, TUDelft pays more attention to cultivating academic and customized professional skills, like 'Turning Your Thesis into Business' and 'Voice Training'. Apart from working competencies, TUDelft also cares about inclusiveness toward disadvantaged groups and mental health. 'Career Strategies for Women in Science' is a workshop during which stakeholders discuss females' attributes, obstacles, and dynamics in the career, then share successful experiences with each other (Delft University of Technology, n.d.). 'Dutch for Foreigners' is a language training for foreign students, in this course will they learn not only linguistic knowledges, but cultural ethos (Delft University of Technology, n.d.). 'How to Keep Motivated after Your GO? Regain Your Flow!' and 'Work Smarter, Stress Less' focus on mental issues and help doctoral students to rebuild motivation during their study. Although Polimi provides professional skills training, but not as systematic as TUDelft.

Furthermore, Kyushu has a different skill training arrangement with other curriculums: it sets individual projects for the five research fields, which are to teach approaches and train skills. Generally, these projects include seminars, lectures, and group works, thus the customized contexts probably help students to recognize what they need efficiently.

\section{Conclusion}

After studying the six curriculums, the researcher has found that Aalto, Polimi, and TUDelft mainly applies the 'Research about Design (RaD)' and 'Research for Design (RfD)' paradigms to educate doctoral students, for they both utilize natural sciences, humanities, and social sciences methods 
toward candidates (Findeli et al., 2008), and their students are expected to produce artefacts, services, and new tacit knowledge (Clementea et al., 2017). On the other side, Tongji, Kyushu, and KAIST apply the 'Research through Design (RtD)' paradigm, this mixed educational model enables students to be design researchers, practitioners, and educators, at the same time they can produce new knowledge of design epistemology (designerly ways of knowing), design praxiology (practices and processes of design), design phenomenology (form and configuration of artefacts) (Cross, 2007). Among them, RaD and RfD have comparatively clear access to conduct pedagogical activities, but RtD seems like a choice during the transformative period, within which potentials and risks are juxtapositions. From the perspective of the researcher, RtD might better suits this social world with increasing uncertainty and complexity, just like conducting a set of unified definitions of design terms are problematic and even unnecessary. Take pandemic influence as an example, education has been compelled to be transferred from offline to distance learning, this drives design to trial resilient pedagogies toward the situation. Therefore, a defined core course group combining extensive interdisciplinary elective courses may be an acceptable solution for current doctoral pedagogy in design. What's more, the regional coordination is essential for education, like the Erasmus project DoCS4Design, which is a long-term international collaboration that aims to support doctoral education in design consist of Aalto, Polimi, TUDelft, Imperial College London, Illinois Institute of Technology Chicago, and Carnegie Mellon University (Aalto Design Research, 2021). Although China has such an organization called Doctoral Forum on Design Research, it limits annual communication between teachers and students, lacking durative and regional cooperation (Tencent, 2015). On this level, Tongji, Kyushu, KAIST, and other Asian universities may consider developing a sustainable partnership for design research education.

\section{References}

Aalto Design Research. [@aalto_design]. (2021, Feb 10). Today we are launcing our DoCS4Design Erasmus+ Design Doctoral project with @tudelft PoliMilano @CarnegieMellon @illinoistech @imperialcollege [Thumbnail with link attached] [Tweet]. Twitter. https://twitter.com/aalto_design/status/1359491110477959172/photo/1

Aalto University. (n.d.). Course offered. https://into.aalto.fi/display/endoctoralarts/Courses+offered

Alpay, H. (1999). Redefining'PhD in Design' in The Periphery: A Critical review of The development Characteristics of The Doctoral Education in Industrial Design in Turkey. In R. Buchanan, D. Doordan, L. Justice, \& V. Margolin (Eds.), Doctoral Education in Design: Proceedings of Ohio Conference (pp. 197-206). Published by the School of Design, Carnegie Mellon University.

Clemente, V., Tschimmel, K., \& Pombo, F. (2017). A Future Scenario for a Methodological Approach applied to PhD Design Research. Development of an Analytical Canvas. The Design Journal, 20(Sup 1), 792-802. https://doi.org/10.1080/14606925.2017.1353025

Cross, N. (2007). From a Design Science to a Design Discipline: Understanding Designerly Ways of Knowing and Thinking. In R. Michel (Ed.), Design Research Now. Board of International Research in Design (pp. 41-54). Birkhäuser Basel.

Delft University of Technology. (n.d.). Centre for Languages and Academic Skills. https://www.tudelft.nl/en/tpm/about-the-faculty/departments/staff-departments/centre-forlanguages-and-academic-skills

Delft University of Technology. (n.d.). Doctoral Education Programme (DE). https://www.tudelft.nl/en/education/programmes/phd/doctoral-education-programme-de 
Delft University of Technology. (n.d.). T4.G8 Career Strategies for women in Science. https://www.tudelft.nl/en/education/programmes/phd/doctoral-education-programmede/training-programme/t4g8-career-strategies-for-women-in-science

Delft University of Technology. (n.d.). TU Delft Graduate School. https://www.tudelft.nl/en/education/programmes/phd/

Department of Industrial Design, Korea Advanced Institute of Science and Technology. (n.d.). https://id.kaist.ac.kr/index.php?mid=history

Durling, D. (2013). Understanding the PhD by Publication. In J. B. Reitan, P. Lloyd, E. Bohemia, L. M. Nielsen, I. Digranes, and E. Lutnæs (Eds.), DRS Cumulus Oslo 2013 - Proceedings of the 2nd International Conference for Design Education Researchers (pp. 1526-1536). ABM-media.

Findeli, A., Brouillet, D., Martin, S., Moineau, C., \& Tarrago, R. (2008). Research through design and transdisciplinarity: A tentative contribution to the methodology of design research. In Swiss Design Network (Ed.), Focused -- Current Design Research Projects and Methods (pp. 67-91). Swiss Design Network.

Friedman, K. (2000). Form and Structure of the Doctorate in Design: Prelude to a Multilogue. In D. Durling \& K. Friedman (Eds.), Doctoral Education in Design. Foundations for the Future. Proceedings of the La Clusaz Conference (pp. 369-376). Staffordshire University Press.

Friedman, K. (2002). Design Curriculum Challenges for Today's University. In A. Davis (Ed.), Enhancing Curriucla: Exploring Effective Curriculum Practices in Art,Design and Communication (pp.27-63). Centre for Learning and Teaching in Art and Design (CLTAD).

Friedman, K. (2015). Writing for the PhD in Art and Design. Issues for Research Supervisors and Research Students [Unpublished manuscript]. Centre for Design Innovation. Swinburne University of Technology.

Jiang, S. H. (1998). 教育结构及其分类发微 [Education structure and its classification].内蒙古师大 学报 (哲学社会科学版)，(2)，62-67.

Li, C. D. (2011). 关于开设《设计前沿》博士课程的思考 [The Thinking on Opening the Doctoral Program of Advanced Design]. 创意与设计, (5), 83-85. https://doi.org/10.3969/J.ISSN.16744187.2011.05.015

Li, L. X. (2012). 艺术学学科发展:一个全新的课题一一南京艺术学院艺术学优势学科建设的思路 [The Development of the Discipline of Art Studies: A Brand-new Subject--The Idea of Constructing the Superior Discipline of Art Studies in Nanjing University of the Arts]. 艺术学研究， 175-179.

Li, M. H. (2015). 中日艺术院校博士研究生培养方式比较探讨 [A Comparative Study on the Training Methods of Doctoral Candidates in Art Colleges in China and Japan]. 艺术教育, (4), 102103.

Margolin, V. (1999). History, Theory, and Criticism in Doctoral Design Education. In R. Buchanan, D. Doordan, L. Justice, \& V. Margolin (Eds.), Doctoral Education in Design: Proceedings of Ohio Conference (pp. 197-206). Published by the School of Design, Carnegie Mellon University.

Margolin, V. (2010). Doctoral Education in Design: Problems and Prospects. Design Issues, 26(3): 7078. http://doi.org/10.1162/desi_a_00031

Melles, G. (2009). Global perspectives on structured research training in doctorates of design - what do we value? Design Studies, 30(3), 255-271. http://doi.org/10.1016/j.destud.2008.09.003

Morrison, A., Vaughan, L., Mainsah, H., \& Ball, C. E. (2015). Dialogue and PhD design supervision. In E. Bohemia, I. Digranes, \& R. V. Zande (Eds.), LearnxDesign 2015 - Proceedings of the 3rd International Conference for Design Education Researchers (pp. 1-13). Aalto University.

Patton, M. Q. (1990). Quatlitaive Evaluation and Research Methods. Newbury Park. 
Politecnico di Milano. (n.d.). PhD level courses. http://www.dottorato.polimi.it/en/during-yourphd/phd-level-courses/index.html

School of Design, Carnegie Mellon University. (n.d.). Doctoral Research. https://design.cmu.edu/content/doctoral-research

School of Design, Kyushu University. (n.d.). History. https://www.design.kyushu-u.ac.jp/en/about/ Shen, W. Q., \& Wang, D. F. (2010). 从欧洲模式到美国模式：欧洲博士生培养模式改革的趋势 [From European Model to American Model : The Trends of Doctoral Training Model Reform in European Countries]. 外国教育研究, 37(8), 69-74.

Tencent. (2015). Review of the 2015 (Tsinghua) First University Design Forum on Design Research. In Tencent: Wechat (Version 8.0.0) [Mobile app]. Wechat. https://mp.weixin.qq.com/s/r1gbhE5YVjkbAHb-14ci2Q

Tongji University. (2020). 博士教育 [Doctoral Education]. https://tjdi.tongji.edu.cn/Channel.do?ID=32\&lang $=\& v=1$

Voûte, E., Stappers, P. J., Giaccardi, E., Mooij, S., \& van Boeijen, A. (2020). Innovating a Large Design Education Program at a University of Technology. Sheji: The Journal of Design, Economics, and Innovation, 6(1), 50-66. https://doi.org/10.1016/j.sheji.2019.12.001

Wang, C. Y., \& Zhao, S. (2017). 21 世纪全球博士教育改革的八大趋势 [On the Eight Tendencies of Global Doctoral Education in the 21st Century]. 教育研究, (2), 142-151.

Whitney, P., \& Nogueira, A. (2020). Cutting Cubes Out of Fog: The Whole View of Design. Sheji: The Journal of Design, Economics, and Innovation, 6(2), 129-156. https://doi.org/10.1016/j.sheji.2020.04.001

Yin, H. (2014). 设计学博士研究生培养模式研究一以中国美术学院为例 [Research on the Cultivation Model of Doctoral Candidates in Design-Taking China Academy of Art as an Example]. 美术大观，(4)，144-145.

Zhang, W. J. (2015). 艺术学博士研究生培养机制研究 [Research on the Cultivation Mechanism of Doctoral Candidates in Art]. 长春教育学院学报, 31(12), 86-88.

工业设计第一位博士产生 [The first PhD in industrial design was produced]. (1991). 时代建筑，(1)， 56.

Author Bios:

Fan Chen is a PhD candidate in Tongji University. His PhD research focuses on the doctoral education system under Chinese context. He has published several academic papers on design education and design practice on Cumulus, IASDR, and DRS. 